\title{
The Quality of Physic Nut (Jatropha curcas) Seeds Affected by Water Activity and Duration of Storage
}

\author{
OKKY SETYAWATI DHARMAPUTRA ${ }^{1,2^{*}}$, RANTJE LILLY WORANG $^{1,3}$, RIZAL SYARIEF $^{4}$ AND MIFTAHUDIN $^{1}$
}

\author{
${ }^{\prime}$ Department of Biology, Faculty of Mathematics and Natural Sciences, Institut Pertanian Bogor, \\ Darmaga Campus, Bogor16680, Indonesia; ${ }^{2}$ Seameo Biotrop, Jalan Raya Tajur Km. 6, PO Box 116, \\ Bogor 16134, Indonesia; ${ }^{3}$ Faculty of Mathematics and Natural Sciences, Universitas Manado State, \\ Tondano 95615, Sulawesi Utara, Indonesia; ${ }^{4}$ Department of Food Science and Technology, Faculty of Agricultural Technology, \\ Institut Pertanian Bogor, Bogor16680, Indonesia
}

\begin{abstract}
The quality of physic nut (Jatropha curcas) seeds should be maintained during storage, either as seeds for seedlings or oil production to be used for biodiesel. The effects of water activity and duration of storage on the quality, i.e. fungal population, lipid, fatty acid and free fatty acid contents, and viability of physic nut seeds were investigated. The results showed that the moisture content of seeds and total fungal population decreased at low water activities, and increased at high water activities $\left(\mathrm{a}_{\mathrm{w}}\right)$. At $\mathrm{a}_{\mathrm{w}} 0.64$, at the beginning of storage and after 20 weeks of storage, total fungal populations were $5.4 \times 10^{3}$ and $1.8 \times 10^{2} \mathrm{cfu} \mathrm{g}^{-1}$ dry basis (db), respectively. At $\mathrm{a}_{\mathrm{w}} 0.93$, at the beginning of storage and after 20 weeks of storage, total fungal populations were $5.0 \times 10^{3}$ and 3.3 x $10^{6} \mathrm{cfu} \mathrm{g}^{-1} \mathrm{db}$, respectively. At the beginning of storage fungi infecting seeds were field fungi, i.e. Cladosporium sp., Colletotrichum sp., Fusarium semitectum, and $F$. verticillioides. The population of field fungi decreased with the increase of storage duration. They were replaced by postharvest fungi, i.e. Aspergillus restrictus, A. penicillioides, Eurotium chevalieri, E. rubrum, Penicillium citrinum, $P$. implicatum and $P$. oxalicum. Lipid content and viability of seeds decreased with the increase of water activities and seed moisture contents, while free fatty acid contents increased with the increase of water activities and seed moisture contents during storage. Fatty acids of lipid were dominated by unsaturated fatty acids, i.e. oleic and linoleic acids. Physic nut seeds could be stored at $\mathrm{a}_{\mathrm{w}}$ 0.64-0.75 up to eight weeks when the seeds will be used for seedling, or up to 16 weeks when they will be used for producing oil.
\end{abstract}

Key words: Jatropha curcas, physic nut, water activity

Physic nut (Jatropha curcas) seeds are good sources of biodiesel. The oil contents in the seeds and in the kernels are 25- $30 \%$ and 50- 60\%, respectively. The oil contains $21 \%$ saturated fatty acids and 79\% unsaturated fatty acids (Gubitz et al. 1999). As the content of unsaturated fatty acids in the oil is high, it is possible that the content of free fatty acids will also increase during storage. Their increase could be minimized by using good packaging and appropriate storage condition. Water activity $\left(\mathrm{a}_{\mathrm{w}}\right)$ or relative humidity and the temperature of storage were the most important physical factors affecting seed quality, because they determine the moisture content of substrate. Safe appropriate content can prevent fungal infection and the hydrolysis of lipid, consequently the quality of seeds or grains could be maintained for longer period. According to Sirisomboon et al. (2007), the moisture content of physic nut hulls (fruits) var. Kanlueang was the highest, compared to its seeds (nuts) and kernels. Wanita and Hartono (2007) reported that seeds originated from physic nut fruits having yellow up to blackish yellow shell colour produce seeds with highest oil content, i.e. $28-30 \%$.

Physic nut seeds can also be used as seeds for seedlings. According to Adikadarsih and Hartono (2006), the use of physic nut seeds for seedlings should be derived from the fruits, which skin is yellow up to blackish yellow in color, because they have high percentages of viability and vigority, i.e. 89 and $81 \%$, respectively. To obtain good quality of physic nut seeds after storage, some factors should be taken into consideration, i.e. the degree of fruit maturity, safe seed

*Corresponding author: Phone: +62-251-8323848, Fax: +62-251-8326851,E-mail: okky_sd@yahoo.com moisture content, appropriate container and storage condition, duration of storage, good viability and vigor of seeds. During storage seeds or grains could be infected by fungi which cause a decrease in viability, discolouration, loss in weight, chemical and nutritional changes, heating, caking and mycotoxin contamination. Chelkowski (1991) reported that in many cases, fungi infecting seeds are seed-borne pathogens. They play an important role in the transmission of numerous pathogenic fungal species to seedlings as well as to the soil.

The objective of this study was to analyze the effects of water activity and duration of seed storage on fungal population; lipid, fatty acid and free fatty acid contents, and viability of physic nut seeds. The population of each fungal species infecting physic nut seeds in various hydratation levels was also determined.

\section{MATERIALSANDMETHODS}

Seed Materials. Physic nut seeds were obtained from fresh harvested fruits having yellow up to blackish yellow shell colour. The fruits were obtained from plants (Lampung accession) cultivated in Loyang Village, Cikedung Subdistrict, Indramayu Regency, West Java in May 2007. The fruit shell were peeled using a knife, then the seeds were air-dried on the selves in a shaded place up to moisture contents of about $8 \%$.

Preparation of Saturated Salt Solution. Selected water activities $\left(\mathrm{a}_{\mathrm{w}}\right)$ were $0.64,0.75,0.84$ and 0.93 using various saturated salt solution, i.e. $\mathrm{NaNO}_{2}, \mathrm{NaCl}, \mathrm{KCl}$ and $\mathrm{KNO}_{3}$, respectively, in sorption containers. The preparation of each salt solution was conducted by placing the salt of certain weight in a sorption container, then distilled water of certain 
volume was added, consequently water activitiy selected was obtained. During storage the salt solutions were still saturated. After being checked using a thermohygrograph at every sampling, the relative humidity inside each sorption container were still the same with that at the beginning of storage.

Packaging and Storing of Physic Nut Seeds. As much as $100 \mathrm{~g}$ of physic nut seeds (moisture content $\pm 8 \%$ ) were placed in a sac made from plastic net. The sack containing the seeds was then hung in a sorption container (10 sacks per container). The seeds were stored in sorption containers with different water activities. Three replicates $(=3$ sorption containers) were used for each water activity. Sorption containers were placed on a wooden table under room conditions. The duration of storages were $0,1,2,3,4,6,8,12$, 16 and 20 weeks. The ambient temperature and relative humidity of the storage room were recorded using a tinytag data logger.

Sampling Method and to Obtain Working Samples. Samples of physic nut seeds were collected from each sack. The seeds derived from each sack in three sorption containers were collected for each storage duration. Each sample derived from each sack was then mixed homogenously, manually divided into five parts to obtain working samples for the determinations of moisture content, fungal population, lipid, fatty acid and free fatty acid contents, and viability of seeds, and reserved sample.

Determination of Seed Moisture Content and Fungal Population. Moisture contents of seeds (based on wet basis) were determined based on oven method. Two replicates were used for each sample. Fungi from each sample were isolated and enumerated using serial dilution method followed by pour plate method on Dichloran 18\% Glycerol Agar (DG18) (Hocking and Pitt 1980). Fungal identification was conducted based on Klich and Pitt (1988), Pitt (1988), Burgess et al. (1994), Barnett and Hunter (1998).

Determination of Lipid, Fatty Acid and Free Fatty Acid Contents and Viability. Lipid, fatty acid and free fatty acid contents were determined based on Soxhlet (AOAC 1999), gas chromatography (AOAC 1984) and titration methods, respectively. Fatty acid contents were determined at the beginning of storage, subsequently after 12 and 20 weeks of storage.

Viability (percentage of germination) of seeds from each sample was determined by growing 25 seeds in a rectangular plastic container $(36 \times 27.5 \times 5 \mathrm{~cm})$ containing sand $(5 \mathrm{~kg} /$ container) seven and 10 days after planting under green house conditions.. Normal seedlings were observed 7 days after planting, while normal, abnormal and death seedlings were observed on 10 days after planting.

Statistical Analysis. Split plot design with two factors was used. The first factor as the main plot was $a_{w}$ with four levels, i.e. $0.64,0.75,0.84$ and 0.93 . The second factor as the subplot was the duration of storage with ten levels, i.e. 0, 1, 2, $3,4,6,8,12,16$ and 20 weeks with three replications. The observed data were analyzed using anova, followed by Duncan's multiple range test at the 5\% probability level.

\section{RESULTS}

Moisture Contents. Seed moisture content is the most important environmental factor that influence fungal growth in stored grains. Moisture content is always in equilibrium with the relative humidity of the storage. The range and the mean of ambient temperature and relative humidity of the storage is presented in Table 1. At the beginning of storage the average moisture contents of physic nut seeds were between $8.17-8.36 \%$ wet basis. Water activity, duration of storage and their interaction gave very significant difference on the moisture contents (Table 2).

At the beginning of storage the moisture contents at $\mathrm{a}_{\mathrm{w}}$ $0.64(8.36 \%)$ was higher and significantly different from those at $\mathrm{a}_{\mathrm{w}} 0.75(8.17 \%)$, but they were not significantly different from those at $\mathrm{a}_{\mathrm{w}} 0.84(8.28 \%)$ and $\mathrm{a}_{\mathrm{w}} 0.93(8.31 \%)$. With the increase of storage duration each $\mathrm{a}_{\mathrm{w}}$ gave different effect on the moisture contents. After one week of storage, the moisture contents at $\mathrm{a}_{\mathrm{w}} 0.64(8.37 \%)$ was not significantly different with those at $\mathrm{a}_{\mathrm{w}} 0.75(8.37 \%)$, but they were very significantly different from those at $\mathrm{a}_{\mathrm{w}} 0.84(9.39 \%)$ and $\mathrm{a}_{\mathrm{w}} 0.93(10.48 \%)$. At $\mathrm{a}_{\mathrm{w}} 0.64$, the moisture contents decreased with the increase of storage duration after two weeks of storage, while at $\mathrm{a}_{\mathrm{w}}>$ 0.64 the moisture contents increased (Table 2).

Fungal Population. Twenty one fungal species and three fungal isolates were isolated at various $\mathrm{a}_{\mathrm{w}}$ during twenty weeks of storage. They were Aspergillus candidus, A. flavus, A. niger, A. penicillioides, A. restrictus, A. tamarii, Aspergillus sp. B, Aspergillus sp. D, Cladosporium sp., C. cladosporioides, Colletotrichum sp., Eurotium chevalieri, E. rubrum, Fusarium semitectum, F. verticillioides, Lasiodiplodia sp., Libertella sp., Penicillium citrinum, $P$. implicatum, P. oxalicum, Wallemia sebi, and three unidentified fungal isolates, i.e. isolates D, F, and I. Cladosporium cladosporioides and $P$. citrinum were always isolated at various $\mathrm{a}_{\mathrm{w}}$ and duration of storage. Water activity, duration of storage and their interaction gave very significant difference on total fungal population. The effect of interaction between $\mathrm{a}_{\mathrm{w}}$ and duration of storage on total fungal population is presented in Table 3. From the beginning of storage until 20 weeks of storage total fungal population were not different at $\mathrm{a}_{\mathrm{w}} 0.64,0.75$ and 0.84 , but they were significantly different from those at $\mathrm{a}_{\mathrm{w}} 0.93$ after 16 and 20 weeks of storage. Water activity of 0.64 and 0.75 are favorable to be used for storing physic nut seeds, because fungal population decreased during storage. Although at $\mathrm{a}_{\mathrm{w}} 0.84$ after 20 weeks of storage

Table 1 The range and mean of temperature and relative humidity of storage room during storage

\begin{tabular}{cccccc}
\hline \multirow{2}{*}{$\begin{array}{c}\text { Duration of } \\
\text { storage } \\
\text { (week) }\end{array}$} & $\begin{array}{c}\text { Temperature } \\
\left({ }^{\circ} \mathrm{C}\right)\end{array}$ & & & \multicolumn{2}{c}{$\begin{array}{c}\text { Relative humidity } \\
(\%)\end{array}$} \\
\cline { 2 - 3 } \cline { 5 - 6 } \cline { 5 - 6 } & Range & Mean & & Range & Mean \\
\hline $0-1$ & $25.1-28.3$ & 26.5 & & $61.7-80.7$ & 72.6 \\
$1-2$ & $24.7-27.9$ & 26.1 & & $63.9-82.4$ & 75.3 \\
$2-3$ & $24.4-27.9$ & 26.0 & & $65.6-82.8$ & 75.8 \\
$3-4$ & $25.1-27.9$ & 26.3 & & $60.0-80.7$ & 71.2 \\
$4-6$ & $25.1-28.7$ & 26.8 & & $58.7-80.7$ & 71.4 \\
$6-8$ & $25.1-28.3$ & 26.3 & & $48.2-78.1$ & 67.8 \\
$8-12$ & $25.1-29.1$ & 26.5 & & $55.2-78.5$ & 69.5 \\
$12-16$ & $25.1-28.3$ & 26.7 & & $46.0-80.7$ & 68.2 \\
$16-20$ & $25.1-28.7$ & 26.8 & & $55.6-82.4$ & 72.8 \\
\hline
\end{tabular}


Table 2 The effect of water activity and duration of storage on moisture content (\% wet basis) of physic nut seeds

\begin{tabular}{cccccc}
\hline $\begin{array}{c}\text { Duration of } \\
\text { storage (week) }\end{array}$ & \multicolumn{7}{c}{ Water activity } \\
\cline { 2 - 6 } & \multicolumn{9}{c}{0.64} & 0.75 & 0.84 & 0.93 \\
\hline 0 & $8.36 \mathrm{rs} \pm 0.12$ & $8.27 \mathrm{st} \pm 0.09$ & $8.28 \mathrm{st} \pm 0.14$ & $8.31 \mathrm{st} \pm 0.06$ \\
1 & $8.37 \mathrm{rs} \pm 0.09$ & $8.37 \mathrm{rs} \pm 0.03$ & $9.39 \mathrm{~m} \pm 0.07$ & $10.48 \mathrm{~g} \pm 0.25$ \\
2 & $8.26 \mathrm{st} \pm 0.03$ & $8.48 \mathrm{r} \pm 0.03$ & 9.701 & \pm 0.02 & $11.11 \mathrm{f} \pm 0.07$ \\
3 & $8.19 \mathrm{tu} \pm 0.01$ & $8.67 \mathrm{q} \pm 0.11$ & 9.821 & \pm 0.08 & $11.27 \mathrm{e} \pm 0.06$ \\
4 & $8.17 \mathrm{tu} \pm 0.03$ & $8.84 \mathrm{p} \pm 0.01$ & $9.96 \mathrm{k} \pm 0.02$ & $11.38 \mathrm{de} \pm 0.02$ \\
6 & $8.09 \mathrm{u} \pm 0.06$ & $8.89 \mathrm{op} \pm 0.02$ & $10.05 \mathrm{jk} \pm 0.04$ & $11.42 \mathrm{~d} \pm 0.01$ \\
8 & $8.01 \mathrm{vw} \pm 0.03$ & $8.99 \mathrm{o} \pm 0.03$ & $10.13 \mathrm{ij} \pm 0.03$ & $11.49 \mathrm{~cd} \pm 0.04$ \\
12 & $7.92 \mathrm{wx} \pm 0.05$ & $9.14 \mathrm{n} \pm 0.07$ & $10.21 \mathrm{hi} \pm 0.02$ & $11.58 \mathrm{c} \pm 0.03$ \\
16 & $7.84 \mathrm{x}$ & \pm 0.06 & $9.29 \mathrm{~m} \pm 0.06$ & $10.29 \mathrm{~h} \pm 0.03$ & $11.75 \mathrm{~b} \pm 0.05$ \\
20 & $7.64 \mathrm{y} \pm 0.07$ & $9.42 \mathrm{~m} \pm 0.07$ & $10.44 \mathrm{~g} \pm 0.11$ & $12.05 \mathrm{a} \pm 0.11$ \\
\hline
\end{tabular}

Means followed by the same letter are not significantly different according to Duncan's multiple range test at the 5\% level.

the total fungal population increased $\left(4.3 \times 10^{5} \mathrm{cfu} \mathrm{g}^{-1}\right.$ dry basis/db), they did not give any significant difference on the population at beginning of storage up to 16 weeks of storage. At $\mathrm{a}_{\mathrm{w}} 0.84$ and 0.93 total fungal population was straight proportional with the increase of storage duration. At the beginning of storage the range of total fungal population was range between $5.0 \times 10^{3}-5.4 \times 10^{3} \mathrm{cfu} \mathrm{g}^{-1} \mathrm{db}$ at various $\mathrm{a}_{\mathrm{w}}$. After 20 weeks of storage the lowest total fungal population was found at $\mathrm{a}_{\mathrm{w}} 0.64\left(1.79 \times 10^{2} \mathrm{cfu} \mathrm{g}^{-1} \mathrm{db}\right)$, while the highest was found at $\mathrm{a}_{\mathrm{w}} 0.93\left(3.25 \times 10^{6} \mathrm{cfu} \mathrm{g}^{-1} \mathrm{db}\right)$. At the beginning of storage the most often fungi isolated were categorized as field fungi, i.e. Colletotrichum sp., Cladosporium spp. and Fusarium spp. The population of these fungi decreased with the increase of storage duration. At low $\mathrm{a}_{\mathrm{w}}(0.64$ and 0.75$)$ total fungal population decreased with the increase of storage duration, while at high $\mathrm{a}_{\mathrm{w}}(0.84$ and 0.93$)$ total fungal population increased with the increase of storage duration.

Lipid Contents. Physic nut seeds contain high lipid. At the beginning of storage and after 20 weeks of storage, the range of lipid contents were between $39.61-40.85 \% \mathrm{db}$ and 29.59-32.46\% db, respectively. Water activity, duration of storage and their interaction gave very significant difference on lipid content. The effect of $\mathrm{a}_{\mathrm{w}}$ and duration of storage on lipid content is presented in Fig 1.

At the beginning of storage lipid contents of each $a_{w}$ were not significantly different. Lipid contents of each $a_{w}$ decreased with the increase of storage duration. At $a_{w} 0.64$, lipid contents decreased during storage, especially after 12 weeks of storage. After 20 weeks of storage lipid contents were significantly different from those at the beginning of storage up to 16 weeks of storage. At $a_{w} 0.75$, lipid contents decreased during storage, especially after 16 weeks of storage. After 16 and 20 weeks of storage lipid contents were not significantly different, but they were significantly different from those at the beginning of storage up to 12 weeks of storage. At the beginning of storage, at $\mathrm{a}_{\mathrm{w}} 0.84$, lipid contents was significantly different from those after one week of storage. Lipid contents decreased continuously up to 20 weeks of storage. After 20 weeks of storage lipid contents was significantly different from those after two up to 16 weeks of storage. At $\mathrm{a}_{\mathrm{w}} 0.93$ lipid, contents decreased significantly during storage, especially after two weeks of storage. After two weeks of storage lipid contents was significantly different from those at the beginning and after one week of storage. Lipid contents decreased continuously up to 16 weeks of storage and they were significantly different from those after 20 weeks of storage. Lipid contents at the four levels of $a_{w}$ decreased with the increase of storage duration, but they were still in the good ranges for oil production (about 30\%). The highest decrease of lipid contents were found at $\mathrm{a}_{\mathrm{w}} 0.93$ after 20 weeks of storage $(29.59 \% \mathrm{db})$. The decrease of lipid contents was in the form of negative sigmoid, it looks like S letter upside-down.

Fatty Acid and Free Fatty Acid Contents. Lipid of physic nut seeds consist of saturated and unsaturated fatty acids. In this study fatty acid contents of physic nut seeds were dominated by unsaturated fatty acids, i.e. oleic acid (37.05$41.29 \% \mathrm{wb})$, followed by linoleic acid (26.73-29.08\% wb).

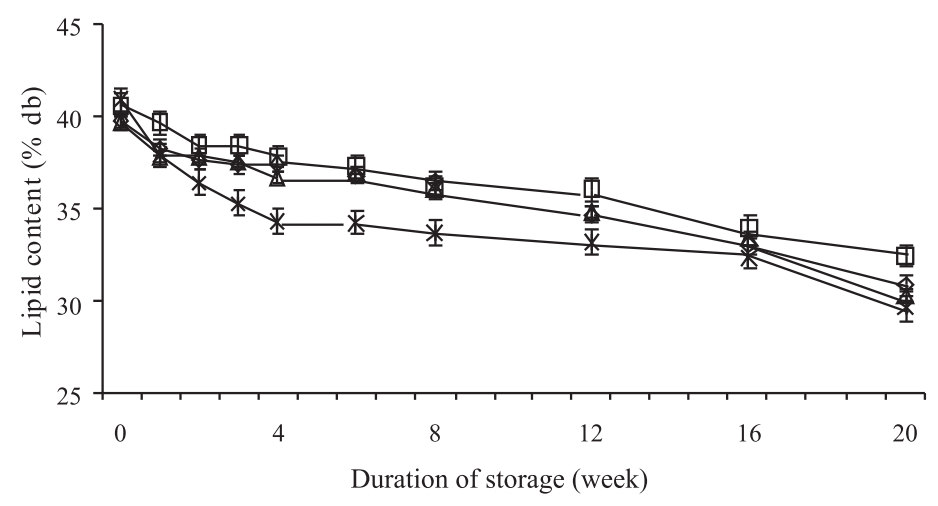

Fig 1 Effect of water activity and duration of storage on lipid content of physic nut seeds. $\diamond$ aw $0.64, \square$ aw $0.75, \quad \triangle$ aw 0.84 , $\rightarrow$ aw 0.93 
Table 3 The effect of water activity and duration of storage on total fungal population (cfu $\mathrm{g}^{-1} \mathrm{db}$ ) of physic nut seeds

\begin{tabular}{|c|c|c|c|c|}
\hline \multirow{2}{*}{$\begin{array}{l}\text { Duration of } \\
\text { storage } \\
\text { (week) }\end{array}$} & \multicolumn{4}{|c|}{ Water activity } \\
\hline & 0.64 & 0.75 & 0.84 & 0.93 \\
\hline 0 & $5.3 \times 103 \mathrm{c} \pm 7.0 \times 10$ & $5.2 \times 103 \mathrm{c} \pm 6.0 \times 102$ & $52 \times 103 \mathrm{c} \pm 3.1 \times 103$ & $5.0 \times 103 \mathrm{c} \pm 1.5 \times 103$ \\
\hline 1 & $4.2 \times 103 c \pm 1.1 \times 103$ & $5.1 \times 103 \mathrm{c} \pm 1.6 \times 103$ & $5.2 \times 103 \mathrm{c} \pm 1.5 \times 103$ & $6.5 \times 103 c \pm 2.3 \times 103$ \\
\hline 2 & $3.6 \times 103 \mathrm{c} \pm 1.3 \times 103$ & $4.2 \times 103 c \pm 2.4 \times 103$ & $5.2 \times 103 \mathrm{c} \pm 2.2 \times 103$ & $8.5 \times 103 \mathrm{c} \pm 1.6 \times 103$ \\
\hline 3 & $2.5 \times 103 \mathrm{c} \pm 4.4 \times 102$ & $3.1 \times 103 c \pm 1.6 \times 103$ & $5.7 \times 103 \mathrm{c} \pm 1.7 \times 103$ & $1.0 \times 104 \mathrm{c} \pm 3.8 \times 103$ \\
\hline 4 & $1.4 \times 103 \mathrm{c} \pm 7.1 \times 102$ & $1.3 \times 103 \mathrm{c} \pm 6.7 \times 102$ & $6.2 \times 103 \mathrm{c} \pm 2.8 \times 103$ & $3.3 \times 104 \mathrm{c} \pm 5.5 \times 103$ \\
\hline 6 & $9.9 \times 102 \mathrm{c} \pm 3.2 \times 102$ & $1.2 \times 103 \mathrm{c} \pm 5.2 \times 102$ & $2.0 \times 104 \mathrm{c} \pm 2.2 \times 103$ & $1.8 \times 105 \mathrm{c} \pm 1.2 \times 105$ \\
\hline 8 & $9.5 \times 102 \mathrm{c} \pm 3.6 \times 102$ & $1.2 \times 103 \mathrm{c} \pm 6.8 \times 102$ & $2.1 \times 104 \mathrm{c} \pm 2.5 \times 103$ & $3.0 \times 105 \mathrm{c} \pm 2.4 \times 105$ \\
\hline 12 & $2.8 \times 102 \mathrm{c} \pm 3.9 \times 102$ & $6.2 \times 102 \mathrm{c} \pm 4.1 \times 102$ & $2.2 \times 104 \mathrm{c} \pm 1.1 \times 103$ & $308591 \mathrm{c} \pm 152907$ \\
\hline 16 & $2.8 \times 102 \mathrm{c} \pm 3.1 \times 102$ & $2.7 \times 102 \mathrm{c} \pm 291.96$ & $2.3 \times 105 \mathrm{c} \pm 1.1 \times 105$ & $1.2 \times 106 \mathrm{~b} \pm 2.1 \times 105$ \\
\hline 20 & $1.8 \times 102 \mathrm{c} \pm 7.3 \times 10$ & $2.7 \times 103 \mathrm{c} \pm 1.4 \times 102$ & $4.3 \times 105 \mathrm{c} \pm 1.2 \times 105$ & $3.3 \times 106 \mathrm{a} \pm 1.3 \times 106$ \\
\hline
\end{tabular}

Means followed by the same letter are not significantly different according to Duncan's multiple range test at the $5 \%$ level.

The composition of fatty acids of physic nut seeds stored at $\mathrm{a}_{\mathrm{w}} 0.64$ and 0.93 at the beginning of storage, subsequently after 12 and 20 weeks of storage is presented in Table 4.

Free fatty acid contents of physic nut seeds at the beginning of storage were between $0.13-0.27 \% \mathrm{db}$. At various $\mathrm{a}_{\mathrm{w}}$ free fatty acid contents increased with the increase of storage duration. Water activity, duration of storage and their interaction gave very significant difference on free fatty acid contents. The effect of $a_{w}$ and duration of storage on free fatty acid content is presented in Fig 2. At the beginning of storage free fatty acid contents at each $a_{w}$ were not significantly different. Nevertheless, free fatty acid contents increased with the increase of storage duration. After 12 weeks of storage free fatty acid contents at $a_{w} 0.64$ was not significantly different from those at $\mathrm{a}_{\mathrm{w}} 0.75$, but they were significantly different from those at $a_{w} 0.84$ and 0.93 . Free fatty acid contents at $1 \%$ concentration were obtained at $a_{w}$ 0.64 and $\mathrm{a}_{\mathrm{w}} 0.75$ after 16 weeks of storage, at aw 0.84 after 12 weeks of storage, and at $\mathrm{a}_{\mathrm{w}} 0.93$ after 6 weeks of storage (Fig 2 ). The requirement of free fatty acid contents of physic nut oil to be used for biodiesel shold not be less than $1 \%$.

Seed Viability. At the beginning of storage the seed germination percentages were $>90 \%$. Nevertheless, at each $\mathrm{a}_{\mathrm{w}}$, the seed germination percentages decreased with the increase of storage duration. At higher $a_{w}$ the decrease of

Table 4 Composition of fatty acids of physic nut seeds stored at $\mathrm{a}_{\mathrm{w}} 0.64$ and 0.93 at the beginning of storage, subsequently after 12 and 20 weeks of storage

\begin{tabular}{lccccccc}
\hline & \multicolumn{6}{c}{ Composition (\% wb) } \\
\cline { 2 - 7 } \multicolumn{1}{c}{ Kind of fatty acid } & \multicolumn{4}{c}{$\mathrm{a}_{\mathrm{w}} 0.64$} & \multicolumn{4}{c}{$\mathrm{a}_{\mathrm{w}} 0.93$} \\
\cline { 2 - 8 } & 0 & 12 & 20 & 0 & 12 & 20 \\
& week & week & week & week & week & week \\
\hline Myristic acid (C14:0) & 0.05 & 0.05 & 0.70 & 0.04 & 0.05 & 0.16 \\
Palmitic acid (C16:0) & 12.00 & 11.57 & 10.57 & 12.36 & 10.9 & 11.57 \\
Stearic acid (C18:0) & 6.89 & 6.49 & 6.56 & 6.97 & 6.23 & 7.28 \\
Oleic acid (C18:1) & 38.47 & 39.13 & 37.2 & 40.42 & 37.05 & 41.29 \\
Linoleic acid (C18:2) & 27.72 & 28.13 & 26.73 & 29.08 & 26.96 & 28.53 \\
Arachidic acid (C20:0) & 0.17 & 0.18 & 0.16 & 0.17 & 0.18 & 0.16 \\
Linolenic acid (C18:3) & 0.19 & 0.24 & 0.22 & 0.22 & 0.22 & 0.23 \\
\hline
\end{tabular}

seed germination percentages was faster than those at lower $\mathrm{a}_{\mathrm{w}}$. Water activity, duration of storage and their interaction gave very significant difference on seed germination percentage. The effect of $a_{w}$ and duration of storage on seed germination percentage is presented in Table 5. At the beginning of storage up to four weeks of storage at each $\mathrm{a}_{\mathrm{w}}$ the percentages of germination were not significantly different. Their percentages of germination were still good (> 80\%). After six and 12 weeks of storage at a $0.64,0.75$ and 0.84 the percentages of germination were not significantly different, but they were significantly different from those at $a_{w}$ 0.93. After eight weeks of storage at $a_{w} 0.64$ and 0.75 the percentages of germination were not significantly different, but they were significantly different from those at $\mathrm{a}_{\mathrm{w}} 0.84$ and 0.93 .

\section{DISCUSSION}

Moisture content is the most important factor which influences fungal growth in stored seeds or grains. High moisture content is favorable for fungal growth. Dirjenbun (2006) determined the safe moisture content for storing physic nut seeds was 7-9\%. In this study the average moisture contents at the beginning of storage were $8.17-8.36 \%$ wet basis (Table 2). Water activity 0.64 was favorable $\mathrm{a}_{\mathrm{w}}$ for storing physic nut seeds up to 20 weeks, because their moisture contents were $7.64-8.37 \%$. Physic nut seeds were still good if stored at $\mathrm{a}_{\mathrm{w}} 0.75 \mathrm{up}$ to eight weeks. Water activity of 0.84 and 0.93 were not favorable to store physic nut seeds, because after one week of storage, their moisture contents increased to more than $9 \%$. The moisture contents of seed or grain is in equilibrium with the relative humidity of the storage. Seeds can have lost (desorption) or absorb (absorbtion) the humidity of their environment. Seeds stored in a room with high relative humidity will absorb the humidity of their environment. On the other hand, seeds will have lost their humidity, if they were stored at low relative humidity. At $\mathrm{a}_{\mathrm{w}} 0.64$ or relative humidity $64 \%$, physic nut seeds had lost their humidity during 20 weeks of storage. Their moisture contents were $8.36 \%$ (at the beginning of storage), and then they became $7.64 \%$ after 20 weeks of storage. At $a_{w}$ e" 0.75 during 20 weeks of storage physic nut seeds absorbed the humidity of their environment. Moisture content of physic nut seeds increased at $\mathrm{a}_{\mathrm{w}} 0.75,0.84$ and 0.93 during 20 weeks 


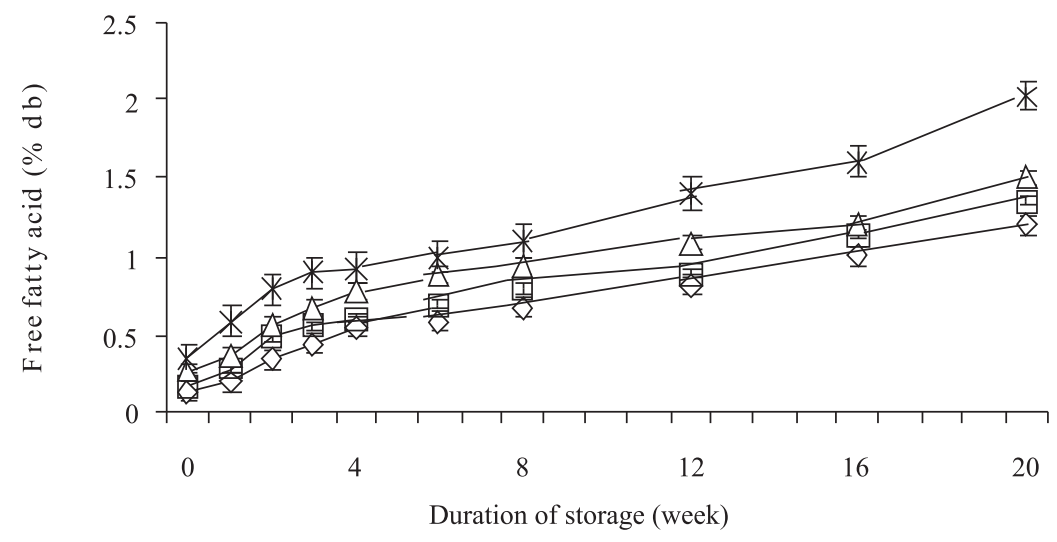

Fig 2 Effect of water activity and duration of storage on free fatty acid content of physic nut seeds. $\checkmark-$ aw $0.64, \square-$ aw 0.75 , $\triangle$ aw $0.84, \rightarrow$ aw 0.93 .

of storage, however, $\mathrm{a}_{\mathrm{w}} 0.64$ can maintain safe moisture content.

At the beginning of storage the most often fungi isolated was field fungi, i.e. Colletotrichum sp., Cladosporium sp., $C$. cladosporioides, $F$. verticillioides and $F$. semitectum. Their population decreased with the increase of storage duration, and then they were replaced by storage fungi.

At $a_{w} 0.64$, total fungal population decreased with the increase of storage duration (Table 3 ). It was assumed that the decrease of total fungal population was due to the constant or the decrease of moisture contents during storage. Moisture content is an important factor affecting fungal growth. At $\mathrm{a}_{\mathrm{w}} 0.75$ total fungal population also decreased, but the decrease was not as fast as at $\mathrm{a}_{\mathrm{w}} 0.64$. According to Douglas and Boyle (1996) low moisture contents inhibited fungal growth, but they did not kill the fungi. Among microorganisms infecting seeds, fungi was the most tolerant to low water availability, therefore they had an important role on seed deterioration. At $\mathrm{a}_{\mathrm{w}} 0.84$ and 0.93 total fungal population increased with the increase of storage duration due to the increase of moisture content. Consequently, fungi infecting physic nut seeds grew and developed better, especially the fungi which have abundant spores such as Aspergillus and Penicillium.The moisture content of seeds was also affected among others by seed respiration and fungal activity. Fungi absorbed the nutrition of seeds and they excreted water as the result of their metabolism. The growth of storage fungi was affected by the moisture content of the substrate, temperature, duration of storage, the level of fungal infection before storage, foreign materials, insects and mites activities. These factors were related one with anothers. Seed coat was the main defense to prevent fungal penetration into the inner seed tissue. The crack of seed which occurred mechanically could give the opportunity of fungi to infect the inner part of the seeds. Seed-borne fungi can cause the decrease of germination.

Lipid or oil of physic nut seeds which contained high unsaturated fatty acid (oleic acid) $(37.05-41.29 \% \mathrm{db}$.), followed by linoleic acid (26.73- $29.08 \% \mathrm{db}$ ) (Table 4) will cause hydrolyses process. This process caused the decrease of lipid and increased free fatty acid contents, either in the seeds or in the oil itself. Lipid contents of physic nut seeds stored at low $\mathrm{a}_{\mathrm{w}}$ decreased with the increase of storage duration, but the decrease was not as rapid as the seeds stored at high $\mathrm{a}_{\mathrm{w}}$ (Fig 1). At high $\mathrm{a}_{\mathrm{w}}$ the moisture contents of physic nut seeds were also high, so they affected the activity of lipolytic fungi to hydrolyse the lipid of the seeds, apart from lipase enzyme produced by the tissue inside of the seeds. Pomeranz (1992) reported that the occurrence of fungi will accelerate the degradation of lipid during storage. The decrease of lipid content was probably due to the activity of lipolytic fungi which grew dominantly and can live for long period. This condition caused the production of free fatty acid and rancidity. Lipid of seeds can be degraded by lipase

Table 5 The effect of water activity and duration of storage on the percentage of physic nut seed germination

\begin{tabular}{|c|c|c|c|c|c|c|c|c|}
\hline \multirow{3}{*}{$\begin{array}{c}\begin{array}{c}\text { Duration of } \\
\text { storage (week) }\end{array} \\
0\end{array}$} & \multicolumn{8}{|c|}{ Water activity } \\
\hline & \multicolumn{2}{|c|}{0.64} & \multicolumn{2}{|l|}{0.75} & \multicolumn{2}{|l|}{0.84} & \multicolumn{2}{|l|}{0.93} \\
\hline & $98.67 \mathrm{a}$ & \pm 2.31 & $98.67 \mathrm{a}$ & \pm 2.31 & $97.33 \mathrm{ab}$ & \pm 2.31 & $94.67 \mathrm{abc}$ & \pm 4.62 \\
\hline 1 & $96.00 \mathrm{abc}$ & \pm 0 & $97.33 \mathrm{ab}$ & \pm 2.31 & $94.67 \mathrm{abc}$ & \pm 2.31 & 90.66 abcdef & $f \pm 2.31$ \\
\hline 2 & $94.67 \mathrm{abc}$ & \pm 2.31 & $96.00 \mathrm{abc}$ & \pm 0 & $92.00 \mathrm{abcd}$ & $\mathrm{de} \pm 0$ & $86.66 \mathrm{cdef}$ & \pm 2.31 \\
\hline 3 & $93.33 \mathrm{abcd}$ & \pm 2.31 & $93.33 \mathrm{abcd}$ & \pm 2.31 & 88.00 bcde & $\mathrm{ef} \pm 0$ & 84.00 defg & \pm 0 \\
\hline 4 & 92.00 abcde & \pm 2.31 & 90.67 abcdef & $\mathrm{f} \pm 2.31$ & $86.67 \mathrm{cdef}$ & \pm 2.31 & $81.33 \mathrm{fg}$ & \pm 2.31 \\
\hline 6 & $86.67 \mathrm{cdef}$ & \pm 2.31 & 88.00 bcdef & \pm 0 & 82.67 efg & \pm 4.62 & $61.33 \mathrm{jk}$ & \pm 2.31 \\
\hline 8 & 84.00 defg & \pm 0 & 88.00 bcdef & \pm 0 & $76.00 \mathrm{gh}$ & \pm 4.00 & 48.001 & \pm 4.00 \\
\hline 12 & $77.33 \mathrm{gh}$ & \pm 4.62 & $76.67 \mathrm{gh}$ & \pm 2.31 & 69.33 hij & \pm 2.31 & $6.67 \mathrm{n}$ & \pm 6.11 \\
\hline 16 & $62.67 \mathrm{ijk}$ & \pm 6.11 & $70.67 \mathrm{hi}$ & \pm 12.86 & $56.67 \mathrm{k}$ & \pm 11.02 & $1.33 \mathrm{n}$ & \pm 2.31 \\
\hline 20 & $29.33 \mathrm{~m}$ & \pm 12.22 & $25.33 \mathrm{~m}$ & \pm 14.05 & $2.67 \mathrm{n}$ & \pm 4.62 & $0.00 \mathrm{n}$ & \pm 0 \\
\hline
\end{tabular}

Means followed by the same letter are not significantly different according to Duncan's multiple range test at the $5 \%$ level. 
into free fatty acid and glycerol, especially if the moisture content of seeds was high. Free fatty acid was an index of deteriorated seeds containing lipid during storage. According to Gupta and Rai (2003) A. fumigatus, A. niger, Alternaria sp., C. cladosporioides and $P$. purpuragenum isolated from soil of dairy dung, house-based waste and mill soil were the good producers of intra- and extracellular lipase activities.

Free fatty acid contents increased with the increase of $a_{w}$ and storage duration. It was assumed, that the ocurrence of various fungal species in physic nut seeds can degrade lipid. According to Pomeranz (1992), Aspergillus, Cladosporium and Penicillium were capable to degrade lipid compound and have high lipolytic activity. These fungal species were often isolated from seeds containing high lipid. At the beginning fungi hydrolyze lipid enzymatically with lipase, and then they was changed into glycerol through ß-oxydation.

The requirement of free fatty acid contents of physic nut oil to be used for biodiesel is $0.8 \%$ (Sudradjat et al. 2007). Free fatty acid contents as much as $1 \%$ at $a_{w} 0.64$ and 0.75 were obtained after 16 weeks of storage (Fig 2). If free acid content was high, they will block the reaction of methyl esther (biodiesel) formation, i.e. methanol, which should react with triglyceride, but methanol formation was prevented by the reaction of soap formation. In this case methanol consumption becomes high as much as $40 \%$ (more expensive), consequently the production of biodiesel decreases as much as $30 \%$. According to Sauer (1988), the decrease of seed quality was followed by the increase of free fatty acid value. The level of free fatty acid value gave an indication concerning the decrease of seed quality. The level of free fatty acid depends on fungal species infecting the seeds. In this study, free fatty acid produced by lipase of physic nut seeds was not separated from that produced by fungi. Dhingra et al. (2001) reported that the viability of soybean seeds inoculated with the conidia of Aspergillus ruber decreased with the increase of free fatty acid and storage duration.

According to Dirjenbun (2006) good seed germination was e" $80 \%$. At the beginning of storage seed germinations were $>90 \%$, nevertheless they decreased at various $a_{w}$ during storage (Table 5). The decrease of germination was very rapid at $\mathrm{a}_{\mathrm{w}} 0.93(<70 \%)$ after 6 weeks of storage with the curve in the form of negative sigmoid. At $\mathrm{a}_{\mathrm{w}} 0.84$ the seed germination percentage was good up to 6 weeks of storage, at $a_{w} 0.75$ it was good up to 12 weeks of storage, while at $a_{w} 0.64$ it was good up to 8 weeks of storage.

Decrease of seed quality was determined by the capability of germination and the vigor at the beginning of storage, the moisture content of seeds, storage condition, and fungal infection. Seed germination was affected by two factors, i.e. internal and external factors. Internal factor consisted of the level of seed maturity, seed size, dormancy and germination inhibitor. External factor consisted water content, temperature, oxygen, light and growth media. Seeds harvested before reaching the level of physiologic maturity was attained, they do not have high viability. Adikadarsih and Hartono (2006) reported that the lowest percentage of physic nut germination (7\%) and vigor (4.3\%) were found in physic nut seeds derived from fruits which fruit skin is green in color, while the highest percentage of germination $(91.67 \%$ ) and vigor $(84.67 \%)$ were found in seeds derived from fruits which fruit skin is yellow in color.

\section{ACKNOWLEDGEMENTS}

The authors gratefully acknowledge Theresia Prawitasari for her suggestions and encoureagement. We would like also to thank the staff members of Plant Pathology and Service Laboratories, Seameo Biotrop, who had in one way or another contributed to this research, and for a BPPS scholarship to Rantje Lilly Worang.

\section{REFERENCES}

Adikadarsih S, Hartono J. 2007. [The effect of fruit maturity on the quality of physic nut seeds. (Jatropha curcas L.)] [in Indonesian]. In: Proceedings of Workshop II: Status Teknologi Tanaman Jarak Pagar. Bogor, Indonesia, 29 Nov 2006. p 143-8.

[AOAC] Association of Official Analytical Chemist. 1984. Official Methods of the Association of Agricultural Analytical Chemists. Arlington: Association of Analytical Chemist, Inc.

[AOAC] Association of Official Analytical Chemist. 1999. Official Methods of Analysis of Food Composition; Additives; Natural Contaminants. $2^{\text {nd }}$ Volume, $16^{\text {th }}$ edition. Gaithersburg: AOAC.

Barnett HL, Hunter BB. 1998. Illustrated Genera of Imperfect Fungi. $4^{\text {th }}$ edition. St. Paul: APS Press.

Burgess LW, Summerell BA, Bullock S, Gott KP, Backhouse D. 1994. Laboratory Manual for Fusarium research. Sydney: University of Sydney.

Chelkowski J. 1991. Fungal pathogens influencing cereal seed quality at harvest. In: Chelkowski J (ed), Cereal Grains; Mycotoxins, Fungi and Quality in Drying and Storage. Amsterdam: Elsevier. p 53-66.

Dhingra OD, Mizubuti ESG, Napoleao IT, Jham G. 2001. Free fatty acid accumulation and quality loss of stored soybean seeds invaded by Aspergillus ruber. Seed Sci Tech 29:193 - 203.

[Dirjenbun] Direktorat Jenderal Perkebunan. 2006. Pedoman Mutu Benih Jarak Pagar Sistem dan Prosedur Pembangunan Sumber Benih dan Peredaran Benih Jarak Pagar. Jakarta: Dirjenbun.

Douglas PL, Boyle R. 1996. Effect of drying control on mycotoxins production. In: Proceedings of $17^{\text {th }}$ ASEAN Technical Seminar on Grain Postharvest Technology; Lumut, Malaysia, 25-27 Jul 1995. p 27-33.

Gubitz GM, Mittelbach M, Trabi M. 1999. Exploitation of the tropical oil seed plant Jatropha curcas L. Biores Technol 67:73-82.

Gupta P, Rai V. 2003. Isolation and screening of lipolytic fungi from Raipur City. Geobios 30:165-8.

Hocking AD, Pitt JI. 1980. Dichloran-glycerol medium for enumeration of xerophilic fungi from low-moisture foods. Appl Environ Microbiol 39:488-92.

Klich MA, Pitt JI. 1988. A Laboratory Guide to Common Aspergillus Species and Their Teleomorphs. North Ryde: Commonwealth Scientific and Industrial Research Organization

Pitt JI. 1988. A Laboratory Guide to Common Lacey Penicillium Species. North Ryde: Commonwealth Scientific and Industrial Research Organization.

Pomeranz Y. 1992. Biological, Functional, and Nutritive Changes of Cereal Grains and Their Product. St. Paul: American of Cereal Chemist Inc. p 55-141.

Sauer DB. 1988. Effects of fungal deterioration on grain : nutritional value, toxicity, germination. Int J Food Microbiol 7:267-75.

Sirisomboon P, Kitchaiya P, Pholpho T, Mahuttanyavanitch W. 2007 Physical and mechanical properties of Jatropha curcas L. fruits, nuts and kernels. Biosystems Eng 97:201-7. 
Sudradjat HR, Setiawan D, Widyawati Y, Ariatmi R, Sahirman. 2007. [The problem of processing technology of biodiesel derived from physic nut oil]. [in Indonesian]. In: Proceedings Workshop II: Status Teknologi Tanaman Jarak Pagar. Bogor, Indonesia, 29 Nov 2006. p 195-212.
Wanita YP, Hartono J. 2007. [The effect of fruit maturity stage on the content of physic nut oil (Jatropha curcas L.)]. [in Indonesian]. In: Proceedings of Workshop II: Status Teknologi Tanaman Jarak Pagar. Bogor, Indonesia, 29 Nov 2006. p 177-80. 